\title{
Pemberdayaan Perempuan Anggota Badan Usaha Milik Desa dengan Pemanfaatan Lahan Kebun Bibit Desa
}

\section{Empowerment of Women Members of the Badan Usaha Milik Desa with Land Utilization of Village Seed Farms}

\author{
Ahmad Mustanir \\ STISIP Muhammadiyah Rappang \\ Sidenreng Rappang Regency, Indonesia \\ ahmadmustanir74@gmail.com
}

\begin{abstract}
Abstrak
Maksud dari kegiatan Pemberdayaan Perempuan Anggota Badan Usaha Milik Desa Melalui Pemanfaatan Kebun Bibit Desa adalah untuk mewujudkan kemandirian ekonomi desa melalui pendampingan perempuan anggota Badan Usaha Milik Desa agar terjadi pemahaman akan pentingnya manajemen organisasi dan administrasi yang tertib dan teratur, pentingnya berorganisasi dan mengatur waktu untuk membantu perekonomian keluarganya melalui pemahaman budidaya pertanian yang lebih baik serta pelaksanaan Participatory Rural Appraisal (PRA) dengan alat kaji permasalahan budidaya pertanian dan Transect untuk lokasi Kebun Bibit Desa.
\end{abstract}

Kata Kunci : Badan Usaha Milik Desa, Kebun Bibit Desa, Participatory Rural Appraisal, Pemberdayaan

\begin{abstract}
The purpose of the Badan Usaha Milik Desa Member Women's Empowerment Activities through the Utilization of Village Seed Gardens is to realize village economic independence through mentoring women Badan Usaha Milik Desa members to understand the importance of orderly and orderly organizational and administrative management, the importance of organizing and managing time to help the family economy through understanding agricultural cultivation better practices and implementation of Rural Appraisal (PRA) with tools to examine the problems of agricultural cultivation and Transect for the location of the Village Seed Farm
\end{abstract}

Keywords: Badan Usaha Milik Desa, Village Seed Farms, Participatory Rural Appraisal, Empowerment 


\section{BAB I}

\section{PENDAHULUAN}

\section{A. Latar Belakang}

Pada hakekatnya perempuan adalah sumberdaya insani yang memiliki potensi yang dapat didayagunakan dalam berbagai bidang dan sektor pembangunan nasional. Populasi penduduk perempuan Indonesia yang cenderung bertambah terus, pada sisi tertentu sering dipandang sebagai masalah kependudukan. Namun pada sisi lain justru memandang populasi penduduk perempuan ini sebagai suatu aset pembangunan.

Di negara-negara berkembang seperti Indonesia pengangkatan harkat dan martabat perempuan sebagai mahluk termulia bersama-sama dengan kaum pria sesungguhnya memiliki sejarah yang panjang. Belajar dari sejarah tersebut yang lebih banyak tertampilkan adalah kaum perempuan yang sering terpinggirkan dibandingkan dengan kaum pria. Seolah-olah pengalaman sejarah itu telah menjadi sumber legitimasi masyarakat untuk mengatakan bahwa perempuan kurang beruntung. Kondisi ini terus berlanjut, sehingga kaum perempuan sendiri telah mempersepsi dan mengkonsepkan diri mereka memang tidak layak untuk menjalankan peran-peran tertentu dalam pembangunan. Namum demikian, pada suatu saat ternyata perjalanan sejarah itulah yang 
membuktikan juga bahwa kaum perempuan telah salah mempersepsi dan mengkonsepkan diri mereka sendiri. Munculnya pahlawan-pahlawan perempuan dalam sejarah perjuangan bangsa Indonesia baik dalam masa sebelum kemerdekaan maupun sesudah kemer dekaan adalah salah satu bukti monumental ternyata perempuan mampu mengaktualisasikan diri secara berdayaguna untuk kepentingan bangsa.

Mencermati fenomena-fenomena keperempuanan seperti yang diuraikan tersebut di atas mengimplikasikan suatu permasalahan yang sangat penting ialah pemberdayaan perempuan. Pentingnya masalah pemberdayaan perempuan tersebut disebabkan pada kenyataannya masih banyak yang belum dapat terberdaya karena berbagai faktor penyebab yang melatar belakanginya. Faktor-faktor tersebut ada yang bersifat eksternal seperti sosial-budaya, kebijakan pemerintah, perundangundangan dan peraturan pelak- sanaannya yang berlaku, faktor geografis, dan kecenderungan-kecenderungan global seperti politik, ekonomi, teknologi komunikasi, dan lain-lain serta faktor-faktor yang bersifat internal seperti persepsi dan konsep diri perempuan, motivasi, stres kerja, aspirasi pekerjaan, dan karakteristik-karakteristik individu lainnya. Berhubung begitu pentingnya masalah pemberdayaan perempuan ini, maka adalah wajar dalam Rakernas Pembangunan Peranan Perempuan 
yang diselenggarakan Kantor Menteri Negara Peranan Perempuan pada tahun 1999 menempatkan pemberdayaan perempuan sebagai salah satu dari lima agenda pokok (Kantor Menteri Peranan Perempuan, 1999).

Saat ini fenomena perempuan bekerja bukan lagi barang aneh dan bahkan dapat dikatakan sudah merupakan tuntutan bagi perempuan untuk berpartisipasi dalam dunia kerja, yang dapat menaikkan harkat perempuan, yang sebelumnya selalu dianggap hanya sebagai pengurus anak, suami dan rumah tangga semata-mata. Bahkan sebelumnya banyak gagasan dan strereotip tentang perempuan sebagai omongan yang acuh tak acuh pada lingkungan, bodoh dan kurang memiliki kemampuan yang akhirnya merendahkan martabat perempuan (Wolfman, 1989).

Pendapat seperti ini biasanya juga tidak berasas dari belenggu nilainilai tradisional yang menjadi tekanan sosial yang mengakar dari pendapat kuno para bangsawan, bahwa perempuan harus selalu ingat akan masak, macak dan manak (memasak, bersolek dan melahirkan anak) sebagai tugas utamanya. Sekarang perempuan dituntut aktif secara ekonomi, meskipun disisi lain ada juga tuntutan agar perempuan yang berkeluarga dapat menghasilkan uang tanpa mengganggu fungsinya sebagai istri dan ibu rumah tangga. 
Penelitian lain yang terkait dengan pekerjaan perempuan dan Revolusi Hijau pada masyarakat Asia dan Afrika adalah penelitian dalam Saptari \& Holzner, (1997) tentang dampak perubahan-perubahan yang disebabkan oleh Revolusi Hijau. Palmer menyatakan bahwa penentu utama perubahan-perubahan dalam pekerjaan perempuan adalah : (1) intensitas tenaga kerja untuk penanaman pada kondisi yang telah ada sebelumnya; (2) persyaratan teknis yang obyektif dari metode yang baru (atau tanaman yang baru); (3) pembagian kerja secara seksual pada keadaan sebelumnya; (4) bentuk-bentuk mekanisme yang diperkenalkan; dan (5) kelas sosial perempuan. Sebuah studi tentang perempuan di sektor informal (Wahyuni, 1990), menunjukkan dua hal, yaitu : 1) perempuan dominan di sektor informal baik di desa maupun di kota, 2) mereka berkonsentrasi dalam suatu aktivitas di sektor informal yang sempit dengan imbalan yang rendah.

Dengan pemberdayaan perempuan desa, harapannya adalah agar mereka mendapat posisi yang sesuai dengan kemampuannya. Misalnya, punya keberanian untuk mengambil resiko dan keputusan dalam menghadapi suatu masalah. Sebab, "pemberdayaan pada hakekatnya merupakan sebuah konsep yang fokusnya adalah hal kekuasaan" (Pranarka dan Moeljarto, 1996). "Pemberdayaan secara substansial merupakan 
proses memutus atau break down dari hubungan antara subyek dengan obyek (A. Mustanir, Justira, Sellang, \& Muchtar, 2018) (Mustanir, Ahmad; Barisan, Barisan; Hamid, 2017) (A. Mustanir \& Jaya, 2016) (A. Mustanir \& Lubis, 2017) (A. Mustanir \& Abadi, 2017) (A. Mustanir, 2017) (A. Mustanir, 2018) (A. Mustanir \& Jusman, 2016) (Damis Dadda, Mustanir, Nilwana, \& Ahmad, 2019) (A. Mustanir \& Rusdi. Muhammad, 2019) (A. Mustanir \& Razak, 2017).

Perempuan disisi lain memiliki peranan penting dalam usaha yang dilakukan disela-sela menunggu musim panen sawah untuk menambah penghasilan bagi keluarganya, Arini Mayanfa'uni (2016), Nasriati (2017). Kondisi di lapangan menunjukkan bahwa pria (petani) hanya membudidayakan tanaman pangan seperti padi, jagung dan palawija lainnya. Sementara itu, mereka tidak memikirkan kebutuhan pangan yang lain seperti sayur mayur dan buah-buahan. Padahal sayur mayur dan buahbuahan merupakan komponen penting bukan hanya dalam menu empat sehat lima sempurna tetapi penjualan hasil sayur mayur dan buah-buahan sangat dibutuhkan keberadaannya dalam menambah pendapatan ekonomi keluarga, belum lagi tanaman-tanaman hias dan tanaman obat keluarga. Usaha pemberdayaan dalam meningkatkan pendapatan keluarga ini bagi ibu-ibu yang mempunyai ketrampilan dan tergabung dalam kelompok 
wanita tani khususnya yang merupakan anggota BUMDes, sudah tentu dapat membantu menambah pendapatan keluarga dengan keterampilannya tersebut, Totok Mardikanto (2015), Edi Suharto (2006). Sedangkan bagi ibu-ibu yang tidak mempunyai ketrampilan, hanya dapat mengandalkan murni dari pendapatan suami yang sebagian besar bermata pencaharian sebagai petani sawah. Hanya saja keterampilan dan kegiatan berorganisasi untuk membantu perekonomian keluarga terkendala pengetahuan pentingnya berorganisasi untuk membantu perekonomian keluarga, manajemen organisasi dan tata tertib administrasi yang belum teratur serta pengaturan waktu pembagian kerja dalam mengurusi organisasi dan usaha pertanian dengan kesibukan di urusan rumah tangga. Di banyak anggota kelompok wanita banyak yang tidak mengerti dan sama pemahamannya tentang budidaya pertanian, serta beberapa anggota memiliki permasalahan dalam mencarikan lahan yang tepat bagi sebagian anggota untuk Kebun Bibit Desa mereka.

Maksud dari kegiatan "Pemberdayaan Perempuan Anggota BUMDes Melalui Pemanfaatan Kebun Bibit Desa" adalah untuk mewujudkan kemandirian ekonomi desa melalui pendampingan perempuan anggota BUMDes agar terjadi pemahaman akan pentingnya manajemen organisasi dan administrasi yang tertib dan teratur, pentingnya 
berorganisasi dan mengatur waktu untuk membantu perekonomian keluarganya melalui pemahaman budidaya pertanian yang lebih baik serta pelaksanaan Rural Appraisal (PRA) dengan alat kaji permasalahan budidaya pertanian dan Transect untuk lokasi Kebun Bibit Desa(Akhmad, Mustanir, \& Ramadhan, 2018) (Razak, Dahong, Ahmad, Dema, \& Mustanir, 2018) (A. D. Mustanir, 2016) (A. Mustanir \& Yasin, 2018) (Mustanir, Ahmad; Abadi, 2016) (Barisan, Ramadhan, \& Mustanir, 2017) (A. Mustanir \& Rusdi, 2019) (A. Mustanir, 2016).

Sedangkan tujuan Pemberdayaan Perempuan Anggota BUMDes Melalui Kebun Bibit Desa adalah:

1. Melakukan pendampingan dan penyuluhan tentang pentingnya bekerjasama dalam berorganisasi dan pembagian kerja untuk menunjang perekonomian keluarga serta pengaturan manajemen dan tata tertib administrasi.

2. Pelatihan dan pendampingan pelaksanaan metode Partisipatory Rural Appraisal (PRA) dengan alat kaji permasalahan budidaya pertanian.

3. Pelatihan dan pendampingan pelaksanaan Transect agar diperoleh gambaran menyeluruh lokasi yang ada sebagai Kebun Bibit Desa.

4. Penyuluhan tentang keorganisasian dan kewirausahaan pertanian. 
5. Membangun sinergitas antara pemerintah, masyarakat, dan swasta dalam rangka mengelola potensi dan meminimalisir permasalahan dalam pemberdayaan BUMDes.

6. Memperkuat sinergisme perguruan tinggi (PT) dengan stakehoder terkait dalam pembangunan desa.

7. Membentuk Desa Sipodeceng sebagai desa mandiri.

Sasaran Pemberdayaan Perempuan Anggota BUMDes adalah mereka (perempuan/wanita) yang tergabung dalam keanggotaan BUMDes atau kelompok wanita tani yang memiliki kepedulian akan kemajuan BUMDes Desa Sipodeceng.

\section{B. Permasalahan}

Perempuan Anggota BUMDes kelompok wanita tani yang memiliki kepedulian akan kemajuan BUMDes Desa Sipodeceng memiliki beberapa permasalahan antara lain:

1) Masih banyak Perempuan Anggota BUMDes/anggota kelompok wanita tani yang belum memiliki pengetahuan pentingnya berorganisasi untuk membantu perekonomian keluarga.

2) Manajemen organisasi dan administrasi organisasi yang masih belum tertib dan teratur. 
3) Banyak Perempuan Anggota BUMDes/anggota kelompok yang tidak mengerti dan sama pemahamannya tentang budidaya pertanian.

4) Pengaturan waktu pembagian kerja dalam mengurusi organisasi dan usaha pertanian dengan kesibukan di urusan rumah tangga .

5) Serta permasalahan kesulitan mencarikan lahan yang tepat bagi sebagian anggota untuk Kebun Bibit Desa (KBD) mereka

\section{Tinjauan Pustaka}

\section{BUMDes}

Kemunculan BUMDes dalam tata kelola pemerintahan desa dilatarbelakangi oleh adanya dorongan terhadap kemandirian dan otonomi di tingkat desa. Desa pada level terbawah diharapkan mampu meciptakan kemandirian guna meningkatkan taraf hidup masyarakat.

Berdasarkan Permendes PDTT nomor 4 tahun 2015 pasal 3 BUMDes didirikan dengan tujuan sebagai berikut :

a. Meningkatkan perekonomian Desa; 
b. Mengoptimalkan aset Desa agar bermanfaat untuk kesejahteraan Desa;

c. Meningkatkan usaha masyarakat dalam pengelolaan potensi ekonomi Desa;

d. Mengembangkan rencana kerja sama usaha antar desa dan/atau dengan pihak ketiga;

e. Menciptakan peluang dan jaringan pasar yang mendukung kebutuhan layanan umum warga;

f. Membuka lapangan kerja;

g. Meningkatkan kesejahteraan masyarakat melalui perbaikan pelayanan umum, pertumbuhan dan pemerataan ekonomi Desa; dan

h. Meningkatkan pendapatan masyarakat Desa dan Pendapatan Asli Desa.

Sehingga untuk mendukung berjalannya tujuan tersebut pemerintah menujukkan keseriusannya dalam mengelola BUMDes dengan mengeluarkan beberapa peraturan tentang BUMDes, diantaranya sebagai berikut:

Pertama, dalam UU nomor 23 tahun 2014 yakni: "desa dapat mendirikan badan usaha milik desa yang sesuai dengan kebutuhan dan 
potensi desa". Kedua, diatur dalam PP nomor 72 tahun 2005 tentang Desa pasal 78 sampai dengan 81 . Ketiga, Peraturan Menteri Dalam Negeri nomor 39 tahun 2010 tentang Badan Usaha Milik Desa. Keempat, UndangUndang nomor 6 tahun 2014 tentang Desa. Kelima, Permendesa nomor 4 tahun 2015 tentang Pendirian Pengurusan Dan Pengelolaan dan Pembubaran Badan Usaha Milik Desa. Dalam peraturan tersebut kurang lebih diatur dengan cukup jelas terkait dengan pendirian BUMDes, pengelolaan, permodalan, dan manfaat BUMDes yang diperuntukkan sepenuhnya bagi masyarakat desa.

Meskipun berbentuk badan usaha namun BUMDes memiliki perbedaan dengan badan usaha pada umumnya. Dalam Buku Panduan Pendirian Pengeloaan BUMDes (2007) dijelaskan bahwa terdapat sedikitnya tujuh ciri utama yang membedakan BUMDes dengan jenis usaha yang laiannya. Pertama, BUMDes bukan milik perseorangan atau individu, namun badan usaha ini dimiliki oleh desa dan dikelola secara bersama. Kedua, modal usaha bersumber dari desa sebesar $51 \%$ dan sisanya bersumber dari masyarakat dan atau dukungan dari sponsor melalui sistem penyertaan modal. Ketiga, memperhatikan budaya lokal. Keempat, BUMDes menyesuaikan dengan potensi yang dimiliki oleh desa. Kelima, keuntungan sepenuhnya diperuntukkan untuk pengelola dan 
masyarakat desa. Keenam, difasilitasi oleh pemerintah provinsi, kabupaten, kota, dan pemerintah desa. Ketujuh, pengawasan dilakukan secara bersama oleh pemerintah desa dan Badan Permusyawaratan Desa (BPD).

\section{Partisipasi dan Partisipasi Masyarakat}

Totok Mardikanto dan Poerwoko Soebiato dalam Ahmad Mustanir (2017: 316-317). Mengemukakan tentang lingkup partisipasi dengan bertolak pada urutan proses perencanaan pembangunan, maka secara rinci jenis partisipasi dalam pembangunan sebagai berikut : 1) Partisipasi dalam pengambilan keputusan, 2) Partisipasi dalam pelaksanaan kegiatan, 3) Partisipasi dalam pemantauan dan evaluasi pembangunan, 4) Partisipasi dalam pemanfaatan hasil-hasil pembangunan.

Menurut Suharto dalam Ahmad Mustanir (2017) Masyarakat adalah sekelompok orang yang memiliki perasaan sama, menyatu satu sama lain karena mereka saling berbagi identitas, kepentingan-kepentingan yang sama, perasaan memiliki, dan biasanya satu tempat yang sama.

Adisasmita dalam Ahmad Mustanir (2017:356-358) mengemukakan bahwa Partisipasi Masyarakat adalah pemberdayaan masyarakat, peran sertanya dalam kegiatan penyusunan perencanaan implementasi program/proyek pembangunan, dan merupakan aktualisasi dan kesediaan 
dan kemauan masyarakat untuk berkorban dan berkontribusi terhadap implementasi Program Pembangunan. Partisipasi masyarakat menurut Isbandi dalam Ahmad Mustanir (2017 : 2-3) adalah keikutsertaan masyarakat dalam proses pengidentifikasian masalah dan potensi yang ada di masyarakat, pemilihan dan pengambilan keputusan tentang alternatif solusi untuk menangani masalah, pelaksanaan upaya mengatasi masalah, dan keterlibatan masyarakat dalam proses mengevaluasi perubahan yang terjadi.

\section{Pemetaan Swadaya dan Participatory Rural Appraisal (PRA)}

Totok Mardikanto dan Poerwoko Soebiato dalam Ahmad Mustanir (2017: 82-84). Mengemukakan tentang lingkup partisipasi dengan bertolak pada urutan proses perencanaan pembangunan, maka secara rinci jenis

Metode dan teknik yang dikembangkan untuk Pemetaan Swadaya merupakan metode yang lebih menekankan pada proses diskusi masyarakat. Alat kajian (tools) yang dikembangkan adalah alat untuk mengajak masyarakat terlibat dalam proses penggalian informasi, analisa dan perumusan masalah/kebutuhan/program, sehingga melalui proses tersebut sebetulnya masyarakat yang terlibat menjadi peneliti bagi dirinya 
dan kehidupan lingkungannya sendiri (Konsultan Manajemen Wilayah - VI P2KP II: 2004)

Dalam Pemetaan Swadaya masalah-masalah yang menjadi hambatan dicari dan digali lebih dalam melalui proses diskusi, survey, dan teknik kajian lainnya sehingga didapatkan gambaran nyata kebutuhan masyarakat yang harus diupayakan pemenuhannya (pemecahan masalah) (KMW PNPM P2KP).

Chambers memperkenalkan metode $P R A$ sebagai alternative bagi para praktisi pembangunan yang memerlukan sebuah metodologi 'penelitian' yang bisa membantu mereka memahami masyarakat secara cepat, dengan informasi aktual, dan biaya murah, serta bisa mengajak masyarakat sebagai pelaku penelitian itu sendiri (Chambers, 1992).

\section{Kebun Bibit Desa (KBD)}

Kebun Bibit Desa (KBD) adalah kebun tempat produksi dan distribusi benih dan bibit milik warga/kelompok/komunitas pelaku Rumah Pangan Lestari (RPL), yang pengelolaanya kelembagaan yang dibentuk oleh warga pelaku RPL desa/kawasan yang bersangkutan. Jenis benih dan bibit yang diproduksi dan di distribusikan terdiri dari Tanaman: sayuran, 
buah-buahan, umbi-umbian, kacang-kacangan, biofarmaka (obat, bumbu). Purnomo (2013)

\section{Manfaat Kegiatan}

Program pengabdian masyarakat ini memiliki 3 (tiga) manfaat, yaitu;

a. Menjadi sarana bagi dosen untuk melaksanakan salah satu Tri Dharma Perguruan Tinggi berupa pengabdian kepada masyarakat.

b. Mendapatkan pengalaman dan kemanfaatan bagi mahasiswa yang merupakan salah satu unsur perguruan tinggi yang memiliki kewajiban tridharma sama seperti dosen.

c. Manfaat ke masyarakat sasaran. Manfaat ini antara lain :

1) Menguatkan kapasitas dan meningkatkan kemampuan pengelolaan usaha Lembaga Ekonomi Desa yang berbasis pada pengolahan potensi desa sesuai dengan kebutuhan masyarakat dan peluang pasar.

2) Akan terjadi pengembangan kemitraan usaha dan pemberdayaannya.

3) Akan terbangun sinergitas antara pemerintah, masyarakat, dan swasta dalam rangka mengelola potensi dan meminimalisir permasalahan dalam pemberdayaan BUMDes. 


\section{E. Sasaran}

Sasaran pelaksanaan program ini adalah Perempuan Anggota BUMDes atau kelompok wanita tani yang memiliki kepedulian akan kemajuan BUMDes Desa Sipodeceng.

\section{F. Target Luaran}

Target luaran adalah Pemberdayaan Anggota Wanita BUMDes Dalam Pengelolaan Kebun Bibit Desa. Selain itu target luaran yang lain adalah terpublikasinya hasil pengabdian dalam proceeding internasional.

\section{G. Metode Penerapan}

Metode dalam penerapan program ini disusun secara sistematis, yang bertujuan untuk memaksimalkan jalannya program, dengan beberapa tahapan pelaksanaan :

1) Diawal kegiatan akan dilakukan silaturahmi dan pengumpulan data awal dengan tokoh masyarakat dan seluruh perempun anggota BUMDes atau kelompok wanita tani yang memiliki kepedulian akan kemajuan BUMDes Desa Sipodeceng untuk lebih mengakrabkan diri 
sehingga kegiatan pendampingan pemberdayaan mereka dapat berjalan lebih maksimal.

2) Sosialisasi pelaksanaan kegiatan pendampingan pemberdayaan perempuan anggota BUMDes atau kelompok wanita tani yang memiliki kepedulian akan kemajuan BUMDes Desa Sipodeceng di tingkat desa agar semua stakeholder di tingkat desa dapat mengetahui adanya kegiatan tersebut serta untuk menyamakan persepsi mengenai kegiatan pendampingan pemberdayaan perempuan anggota BUMDes atau kelompok wanita tani yang memiliki kepedulian akan kemajuan BUMDes Desa Sipodeceng. (Bidang Manajemen).

3) Observasi lapangan dengan melihat Kebun Bibit Desa (KBD) binaan perempuan anggota BUMDes atau kelompok wanita tani yang memiliki kepedulian akan kemajuan BUMDes Desa Sipodeceng. Kegiatan ini untuk mengetahui dengan persis keadaan sebenarnya dan potensi yang dimiliki Kebun Bibit Desa (KBD) binaan perempuan anggota BUMDes atau kelompok wanita tani yang memiliki kepedulian akan kemajuan BUMDes Desa Sipodeceng. (Bidang Manajemen). 
4) Pelatihan metode Transect agar dapat mengetahui kondisi desa dan potensinya sehingga dapat mengetahui lokasi yang tepat bagi pembukaan Kebun Bibit Desa (KBD) yang baru bagi anggota kelompok. (Bidang Produksi).

5) Pelatihan Partisipatory Rural Appraisal (PRA) dengan alat kaji permasalahan budidaya pertanian/perkebunan agar anggota kelompok mengerti dan memiliki pemahaman yang sama dan mendalam tentang budidaya pertanian. (Bidang Produksi dan Bidang Manajemen).

6) Pendampingan pelaksanaan transect di seluruh dusun Desa Sipodeceng untuk memastikan bahwa pelaksanaan transect berjalan sesuai dengan prinsip-prinsipnya dan diperoleh data yang tepat tentang pembukaan Kebun Bibit Desa (KBD) yang baru bagi perempuan anggota BUMDes atau kelompok wanita tani yang memiliki kepedulian akan kemajuan BUMDes Desa Sipodeceng tersebut. (Bidang Produksi).

7) Pendampingan pelaksanaan metode Partisipatory Rural Appraisal (PRA) dengan alat kaji permasalahan budidaya pertanian di seluruh dusun Desa Sipodeceng. Ini dilakukan agar perempuan anggota BUMDes atau kelompok wanita tani yang memiliki kepedulian akan 
kemajuan BUMDes Desa Sipodeceng dapat menerapkan hasil Pelatihan Partisipatory Rural Appraisal (PRA) dengan alat kaji permasalahan budidaya pertanian sesuai dengan ilmu yang diperoleh pada pelatihan. Dengan demikian anggota kelompok dapat mengerti dan memiliki pemahaman yang sama serta mendalam dalam menerapkan PRA ini pada budidaya pertanian di Kebun Bibit Desa. (Bidang Manajemen, Bidang Produksi dan Bidang Pemasaran).

8) Penyuluhan pentingnya berorganisasi kelompok untuk membuka wawasan baru kaum perempuan dalam mengembangkan pertanian melalui perempuan anggota BUMDes atau kelompok wanita tani yang memiliki kepedulian akan kemajuan BUMDes Desa Sipodeceng. (Bidang Organisasi dan Bidang Manajemen).

9) Penyuluhan wirausaha pertanian dengan melibatkan pihak-pihak terkait yang berkompeten (Bidang Produksi dan Bidang Pemasaran). 10) Penyiapan Kebun Bibit Desa (KBD) sesuai hasil Transect dan kajian permasalahan budidaya pertanian di Partisipatory Rural Appraisal (PRA). (Bidang Manajemen dan Bidang Produksi). 


\section{H. Jadwal Pelaksanaan}

\section{Tabel. 1}

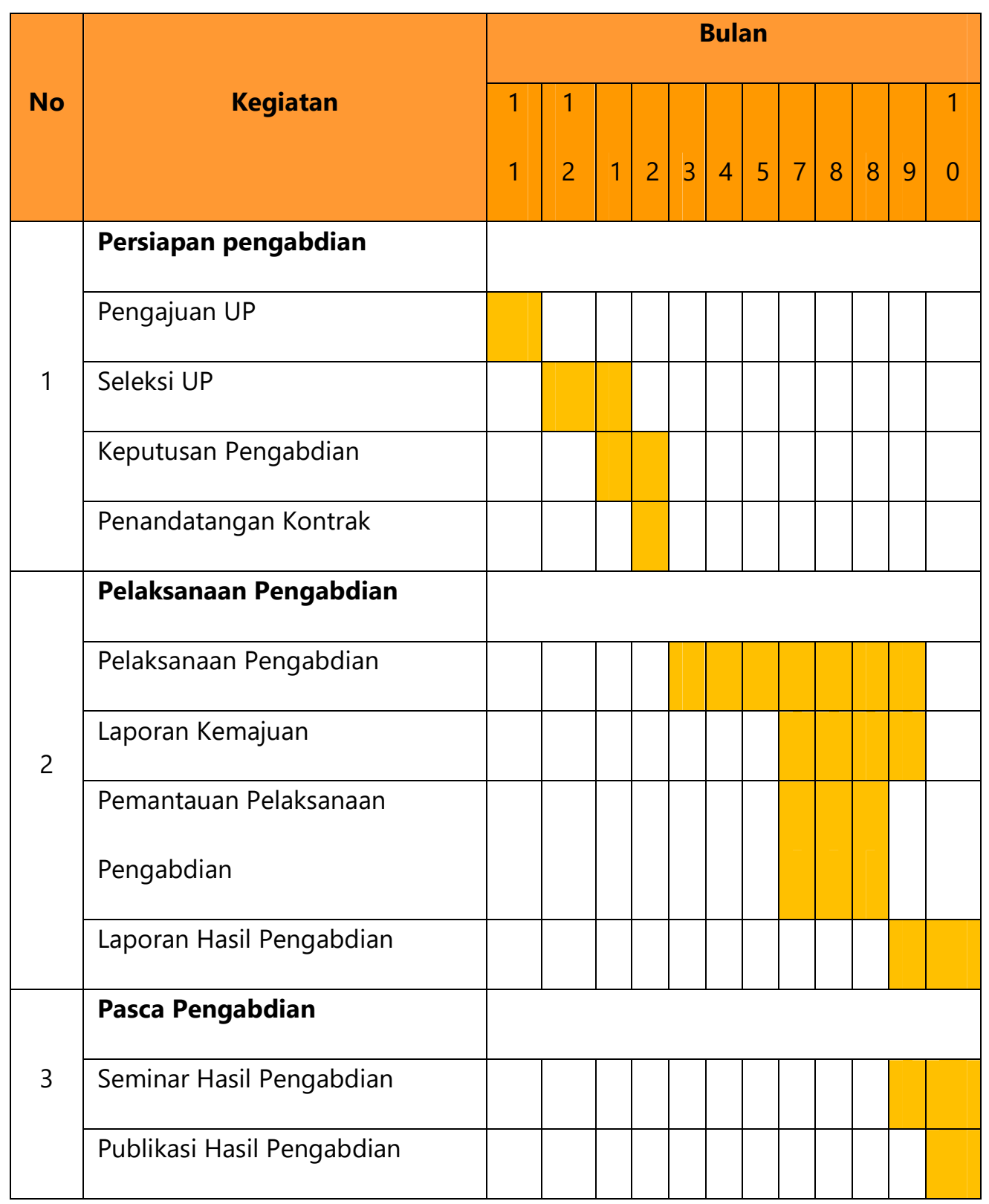




\section{BAB II}

\section{GAMBARAN LOKASI}

\section{A. Kondisi Geografis}

Adapun kondisi umum Desa terdiri dari batas wilayah, orbitas, waktu tempuh, letak desa, iklim, jumlah penduduk, pendidikan sarana dan prasarana, kepemilikan hewan ternak, berikut akan di jelaskan secara rinci:

Letak Batas Desa Sipodeceng adalah :

\begin{tabular}{|l||l||}
\hline \hline Sebelah Utara & Desa Passeno \\
\hline \hline Sebelah Selatan & Kelurahan Manisa \\
\hline Sebelah Barat & Kabupaten Pinrang \\
\hline Sebelah Timur & Kelurahan Baranti \\
\hline \hline
\end{tabular}

Desa Sipodeceng terbagi menjadi 3 Dusun, yaitu Dusun Padaccengga, Dusun Dea dan Dusun Bonginge, terdiri dari 6 Rukun Warga (RW) dan 19 Rukun Tetangga (RT).

Tabel ini akan menjelaskan tentang orbitasi, waktu tempuh dan letak Desa:

\begin{tabular}{|c|l||c|}
\hline NO. & \multicolumn{1}{|c|}{ Orbitasi Jarak Tempuh } & Keterangan \\
\hline \hline 1. & Jarak ke Ibukota Kecamatan & $3 \mathrm{Km}$ \\
\hline \hline 2. & Jarak Ke Ibukota Kabupaten & $17 \mathrm{Km}$ \\
\hline \hline 3. & Jarak Ke Ibukota Provinsi & $187 \mathrm{Km}$ \\
\hline \hline 4. & Waktu tempuh Ke Ibukota Kecamatan & $15 \mathrm{Menit}$ \\
\hline
\end{tabular}

\section{B. Kondisi Demografis}

Berdasarkan luas wilayah yang dimiliki, di Desa Sipodeceng terbagi 
menjadi 3 Dusun yaitu, Padaccenga, Dea, dan Bonginge. Adapun menurut data Pusat statistik Kabupaten Sidenreng Rappang. Desa Sipodeceng dalam angka 2017, jumlah penduduk Desa Sipodeceng kecamatan Baranti dengan rincian sebagai berikut:

- Laki-Laki : 1.544 Jiwa

- Perempuan : 1.794 Jiwa

Total penduduk Desa Sipodeceng berjumlah 3.338 jiwa dengan

- Jumlah kepala keluarga : $1.056 \mathrm{KK}$

\section{Mata Pencaharian Pokok}

\begin{tabular}{|c|l|c|}
\hline No. & \multicolumn{1}{|c|}{ Mata Pencaharian } & Jumlah \\
\hline 1. & Petani & 250 \\
\hline 2. & Pedagang & 31 \\
\hline 3. & PNS & 23 \\
\hline 4. & Buruh & 40 \\
\hline
\end{tabular}

\section{Pendidikan}

\begin{tabular}{|c|l|c|}
\hline No. & \multicolumn{1}{|c|}{ Tingkat pendidikan } & Jumlah \\
\hline 1. & Tidak tamat SD & 170 \\
\hline 2. & SD & 301 \\
\hline 3. & SMP & 200 \\
\hline 4. & SLTA & 145 \\
\hline 5. & SARJANA & 55 \\
\hline
\end{tabular}

Adapun mata pencaharian utama masyarakat Desa Sipodeceng adalah petani. Tanaman padi merupakan komoditi unggulan dengan luas sawah sekitar 689,77 Ha/m2. 
Halaman - 24

Unsgul, Profesional, Islami 


\section{BAB III}

\section{GAMBARAN KEGIATAN}

\section{A. Mekanisme Pelaksanaan Kegiatan}

Secara menyeluruh untuk menyelesaikan permasalahan dan terlaksananya kegiatan pengabdian masyarakat ini dengan baik, kegiatan akan dilaksanakan dengan tahapan metode dan pendekatan sebagai berikut :

1) Diawal kegiatan akan dilakukan silaturahmi dan pengumpulan data awal dengan tokoh masyarakat dan seluruh perempuan anggota BUMDes atau kelompok wanita tani yang memiliki kepedulian akan kemajuan BUMDes Desa Sipodeceng untuk lebih mengakrabkan diri sehingga kegiatan pendampingan pemberdayaan Kelompok dapat berjalan lebih maksimal.

2) Sosialisasi pelaksanaan kegiatan pendampingan pemberdayaan perempuan anggota BUMDes atau kelompok wanita tani yang memiliki kepedulian akan kemajuan BUMDes Desa Sipodeceng di tingkat desa agar semua stakeholder di tingkat desa dapat mengetahui adanya kegiatan tersebut serta untuk menyamakan persepsi mengenai kegiatan pendampingan pemberdayaan. (Bidang Manajemen). 
3) Observasi lapangan dengan melihat Kebun Bibit Desa (KBD) binaan perempuan anggota BUMDes atau kelompok wanita tani yang memiliki kepedulian akan kemajuan BUMDes Desa Sipodeceng. Kegiatan ini untuk mengetahui dengan persis keadaan sebenarnya dan potensi yang dimiliki Kebun Bibit Desa (KBD). (Bidang Manajemen).

4) Pelatihan metode Transect agar dapat mengetahui kondisi desa dan potensinya sehingga dapat mengetahui lokasi yang tepat bagi pembukaan Kebun Bibit Desa (KBD) yang baru bagi anggota kelompok. (Bidang Produksi).

5) Pelatihan Partisipatory Rural Appraisal (PRA) dengan alat kaji permasalahan budidaya pertanian/perkebunan agar anggota kelompok mengerti dan memiliki pemahaman yang sama dan mendalam tentang budidaya pertanian. (Bidang Produksi dan Bidang Manajemen).

6) Pendampingan pelaksanaan transect di seluruh dusun Desa Sipodeceng untuk memastikan bahwa pelaksanaan transect berjalan sesuai dengan prinsip-prinsipnya dan diperoleh data yang tepat tentang pembukaan Kebun Bibit Desa (KBD) yang baru bagi anggota kelompok wanita tani tersebut. (Bidang Produksi). 
7) Pendampingan pelaksanaan metode Partisipatory Rural Appraisal (PRA) dengan alat kaji permasalahan budidaya pertanian di seluruh dusun Desa Sipodeceng. Ini dilakukan agar anggota kelompok wanita tani dapat menerapkan hasil Pelatihan Partisipatory Rural Appraisal (PRA) dengan alat kaji permasalahan budidaya pertanian sesuai dengan ilmu yang diperoleh pada pelatihan. Dengan demikian anggota kelompok dapat mengerti dan memiliki pemahaman yang sama serta mendalam dalam menerapkan PRA ini pada budidaya pertanian di Kebun Bibit Desa. (Bidang Manajemen, Bidang Produksi dan Bidang Pemasaran).

8) Penyuluhan pentingnya berorganisasi kelompok untuk membuka wawasan baru kaum perempuan dalam mengembangkan pertanian melalui perempuan anggota BUMDes atau kelompok wanita tani yang memiliki kepedulian akan kemajuan BUMDes Desa Sipodeceng. (Bidang Organisasi dan Bidang Manajemen).

9) Penyuluhan wirausaha pertanian dengan melibatkan pihak-pihak terkait yang berkompeten (Bidang Produksi dan Bidang Pemasaran).

10) Penyiapan Kebun Bibit Desa (KBD) sesuai hasil Transect dan kajian permasalahan budidaya pertanian di Partisipatory Rural Appraisal (PRA). (Bidang Manajemen dan Bidang Produksi). 


\section{B. Partisipasi mitra dalam pelaksanaan program}

Partisipasi perempuan anggota BUMDes atau kelompok wanita tani yang memiliki kepedulian akan kemajuan BUMDes Desa Sipodeceng dalam program ini dilakukan sejak tahap awal sosialisasi, perencanaan, pelaksanaan dan monev untuk keberlanjutan program. Uraian partisipasi dari perempuan anggota BUMDes atau kelompok wanita tani yang memiliki kepedulian akan kemajuan BUMDes Desa Sipodeceng dapat dilihat pada tahapan metode dan pendekatan seperti yang di uraikan diatas.

\section{Monitoring dan evaluasi pelaksanaan program dan keberlanjutan program di lapangan}

Monitoring dilakukan dengan mencatat perkembangan, memantau proses dan kemajuan pelaksanaan kegiatan secara terus-menerus, mengidentifikasi masalah dan penyimpangan yang muncul, merumuskan pemecahan masalah, dan membuat laporan kemajuan secara rutin dalam kurun waktu yang ditentukan. Kegiatan evaluasi dilakukan dengan mengkaji relevansi, efisiensi, efektivitas dan dampak suatu kegiatan dengan tujuan yang ingin dicapai. 
Monev dilakukan dimulai dari sosialisasi kegiatan pendampingan, perencanaan, pelaksanaan dan keberlanjutan program. Ini digunakan untuk memperbaiki kualitas pelaksanaan dan penyesuaian terhadap perencanaan program. Pelaksanaan monev dilakukan dalam waktu yang bersamaan, tergantung dari waktu pelaksanaan masing-masing program.

Bagian dari pelaksanaan Monev, terdiri atas 2 jenis, yaitu :

1. Monitoring Khusus, meliputi bagian kegiatan persiapan yang fokus kepada perempuan anggota BUMDes atau kelompok wanita tani yang memiliki kepedulian akan kemajuan BUMDes Desa Sipodeceng.

2. Monitoring Umum, meliputi bagian kegiatan proses \& output yang fokus kepada pencapaian tujuan kegiatan pendampingan Program Kemitraan Masyarakat.

Selain itu akan dilakukan monev internal yaitu monev yang dilakukan oleh tim pendamping, dan perempuan anggota BUMDes atau kelompok wanita tani yang memiliki kepedulian akan kemajuan BUMDes Desa Sipodeceng sendiri. Prosedur monev internal ini dapat dilakukan dengan melakukan observasi langsung, wawancara, dan penyebaran cek list.

Monev eksternal dilakukan secara independen, oleh pihak lain. Monev eksternal ini dilakukan oleh pihak lain yang tidak secara langsung 
terlibat dalam pelaksanaan kegiatan. Seperti dari pihak pemerintah desa dan Lembaga Pengabdian Masyarakat (LPM) STISIP Muhammadiyah Rappang.

\section{Bahan dan Peralatan}

Dalam pelaksanaan kegiatan ini, digunakan beberapa alat sebagai perlengkapan jalannya kegiatan atau mendukung kegiatan dalam mencapai hasil yang maksimal. Beberapa alat bahan yang digunakan yaitu: Laptop, Infokus/LCD, Spidol, Kertas Plano, Karton warna, dan Lakban kertas.

\section{E. Indikator Keberhasilan}

Ditahap pelaksanaan prasyarat dari keberlangsungan program terletak pada tahapan sosialisasi tingkat desa dengan pernyataan kesiapan warga khususnya perempuan anggota BUMDes atau kelompok wanita tani yang memiliki kepedulian akan kemajuan BUMDes Desa Sipodeceng. Jika hal ini diterima oleh warga maka keberlangsungan program akan berjalan sesuai dengan tujuan dan harapan. Di pasca pelaksanaan sangat tergantung dari proses yang telah dijalankan. Jika masyarakat khususnya 
perempuan anggota BUMDes atau kelompok wanita tani yang memiliki kepedulian akan kemajuan BUMDes Desa Sipodeceng dilibatkan sejak awal dalam perencanaan dengan menjadikan mereka sebagai subjek dalam pelaksanaan program, maka masyarakat akan merasa memiliki terhadap program dan akan menjaga agar program tersebut tetap berkelanjutan.

Setelah program selesai keberlanjutan program in Shaa Allah dapat terus berjalan karena dari sisi Bidang Kelembagaan (Organisasi) dan Bidang Produksi khususnya keterampilan berwirausaha pertanian diharapkan telah meningkat yang akan memotivasi perempuan anggota BUMDes atau kelompok wanita tani yang memiliki kepedulian akan kemajuan BUMDes Desa Sipodeceng terus menjalankan kewirausahaan pertaniannya.

\section{F. Monitoring dan Evaluasi Kegiatan}

Monitoring dilakukan untuk mencatat perkembangan, memantau proses dan kemajuan pelaksanaan kegiatan secara terus-menerus, mengidentifikasi masalah dan penyimpangan yang muncul, merumuskan pemecahan masalah, dan membuat laporan kemajuan secara rutin dalam 
kurun waktu yang ditentukan. Kegiatan evaluasi dilakukan untuk mengkaji relevansi, efisiensi, efektivitas dan dampak suatu program sesuai dengan tujuan yang ingin dicapai. Untuk melakukan monitoring dan evaluasi pelaksanaan memerlukan data dan informasi yang tepat waktu, akurat, relevan dan lengkap.

Monev dilakukan dimulai dari pelatihan mahasiswa fasilitator pendamping, sosialisasi, perencanaan, pelaksanaan dan keberlanjutan program. Ini digunakan untuk memperbaiki kualitas pelaksanaan dan penyesuaian terhadap perencanaan program.

Pelaporan hasil monitoring dan evaluasi dilakukan oleh semua pihak yang terlibat sebagai pelaku monev. Pelaporan hasil monev dilakukan secara teratur dan berkala serta disusun dalam bentuk laporan lengkap dan laporan populer yang sederhana, menarik, dan mudah dipahami.

Pelaksanaan monev dilakukan dalam waktu yang bersamaan, tergantung dari waktu pelaksanaan masing-masing program.

Bagian dari pelaksanaan Monev, terdiri atas 2 jenis, yaitu :

1. Monitoring Khusus, meliputi bagian kegiatan persiapan yang fokus kepada dosen dan mahasiswa fasilitator pendamping.

2. Monitoring Umum, meliputi bagian kegiatan proses \& output yang fokus kepada masyarakat. 
Selain itu akan dilakukan monev internal yaitu monev yang dilakukan oleh pelaksana kegiatan, lembaga pemberi dana yaitu STISIP Muhammadiyah Rappang dan penerima manfaat/masyarakat. Prosedur monev internal ini dapat dilakukan dengan melakukan observasi langsung, wawancara, dan penyebaran cek list.

Monev eksternal dilakukan secara independen, oleh organisasi lain. Monev eksternal ini dilakukan oleh pihak luar yang independen dan badan yang independen yang tidak secara langsung terlibat dalam pelaksanaan kegiatan. Pemantauan eksternal diharapkan dapat memberi pandangan yang lebih obyektif misalnya dari pihak kopertis/ristekdikti jika diperlukan.

\section{G. Keberlanjutan Dari Program Pengabdian Yang Dilaksanakan}

Setelah program selesai keberlanjutan program dapat terus berjalan karena metode yang dijalankan sejak awal dengan melibatkan warga sejak sosialisasi dan perencanaan dengan menumbuhkan nilai-nilai kemanusiaan dan kemasyarakatan diharapkan akan membuat masyarakat merasa memiliki terhadap program dan kelembagaan yang ada, sehingga masyarakat akan ikut dalam mengawasi pelaksanaan program dan menjaga keberlanjutan program ini berdasarkan program yang telah disusun dalam RPJMDes. 


\section{H. Hambatan-Hambatan Yang Dihadapi Di Lapangan}

Hambatan-hambatan yang dihadapi dalam program pengabdian ini yaitu:

1. Pelaksanaan waktu yang singkat dalam menumbuhkan kesadaran masyarakat akan pentingnya berhimpun dalam kelompok-kelompok kewirausahaan.

2. Menjalin kesepahaman diantara seluruh stakeholder pemberdayaan BUMDes. 


\section{BAB IV}

\section{PENUTUP}

\section{Kesimpulan dan Saran}

1) Perlunya dorongan pemerintah dalam pemberdayaan Perempuan Anggota BUMDes/anggota kelompok wanita tani

2) Perlunya dilakukan banyak kegiatan pelatihan-pelatihan menyangkut manajemen organisasi dan administrasi organisasi bagi Perempuan Anggota BUMDes.

3) Perlunya keterlibatan pemerintah desa dalam mencarikan lahan yang tepat bagi Perempuan Anggota BUMDes/anggota kelompok wanita tani untuk Kebun Bibit Desa (KBD) mereka. 


\section{DAFTAR PUSTAKA}

\section{Buku dan Jurnal}

Barokah, Hindun dkk. Cet 1 2015. Buku Indeks Pembangunan Desa 2014. Jakarta : Kementrian PPN/Bappenas dan BPS.

Chambers, Robert. 1992. Memahami Desa Secara Partisipatif. Yogyakarta : Kanisius dan Oxfam.

Direktorat PSD. 2015. Indeks Desa Membangun. Jakarta: Kemendesa, PDIT.

Hamidi, Hanibal (Ketua Tim Penyusun) dkk. Indeks Desa Membangun 2015. Jakarta: Kementerian Desa, Pembangunan Daerah Tertinggal dan Transmigrasi.

Isbandi. 2007. Perencanaan Partisipatoris Berbasis Aset Komunitas: dari Pemikiran Menuju Penerapan. Depok: FISIP UI Press .

Konsultan Manajemen Wilayah - VI P2KP II. 2004. Modul Pelatihan Pemetaan Swadaya dan Perencanaan Partisipatif Bagi Fasilitator. Palu.

Mardikanto, Totok dan Poerwoko Soebiato. 2015. Pemberdayaan Masyarakat Dalam Perspektif Kebijakan Publik. Bandung : Alfabeta

Akhmad, I., Mustanir, A., \& Ramadhan, M. R. (2018). Pengaruh Pemanfaatan Tekhnologi Informasi dan Pengawasan Keuangan Daerah Terhadap Kualitas Laporan Keuangan Kabupaten Enrekang. In Prosiding Konferensi Nasional Ke-7 Asosiasi Program Pascasarjana Perguruan Tinggi Muhammadiyah Aisyiyah (APPPTMA). Jilid 2. Sosial Politik dan Ekonomi (pp. 89-103). Retrieved from http://asosiasipascaptm.or.id/index.php/publikasi/konferensi-appptmke-7-meningkatkan-kualitas-dan-kuantitas-jurnal-ilmiah

Barisan, B., Ramadhan, M. R., \& Mustanir, A. (2017). Sidenreng Rappang Versus Masyarakat Ekonomi Asean. In The 2nd Journal of Government and Politics International Conference (Vol. II, pp. 258 - 262). Yogyakarta: Penerbit Program Pascasarjana Universitas Muhammadiyah Yogyakarta. Retrieved from http://jksg.umy.ac.id/proceeding-2nd-jgp/

Damis Dadda, A., Mustanir, A., Nilwana, A., \& Ahmad, J. (2019). Pengaruh Kepemimpinan Lurah Perempuan Terhadap Stabilitas Kamtibmas Di Kelurahan Rappang Kabupaten Sidenreng Rappang. In Konferensi 
Nasional Ke-8 Asosiasi Program Pascasarjana Perguruan Tinggi Muhammadiyah Aisyiyah (APPPTMA) (pp. 378-383). Medan: Program Pascasarjana Universitas Muhammadiyah Yogyakarta. Retrieved from http://asosiasipascaptm.or.id/index.php/publikasi/prosiding-

konferensi-nasional-appptma-ke-8

Mustanir, Ahmad; Abadi, P. (2016). PARTISIPASI MASYARAKAT DALAM MUSYAWARAH RENCANA PEMBANGUNAN DI KELURAHAN KANYUARA KECAMATAN WATANG SIDENRENG KABUPATEN SIDENRENG RAPPANG. Jurnal Politik Profetik, 5(2), 247-261. Retrieved from http://journal.uinalauddin.ac.id/index.php/jpp/article/viewFile/4347/3986

Mustanir, Ahmad; Barisan, Barisan; Hamid, H. (2017). Participatory Rural Appraisal As The Participatory Planning Method Of Development Planning. In P. K. Nanang Haryono, Agie Nugroho Soegiono, Putu Aditya Ferdy Ariawantara (Ed.), Indonesian Association for Public Administration (IAPA) International Conference Towards Open Government: Finding the Whole Government Approach (pp. 77-84). Surabaya: The Faculty Of Social And Political Science Universitas Airlangga. Retrieved from http://conference.unair.ac.id/index.php/IAPA/iapa2017

Mustanir, A. (2016). Perencanaan Mewujudkan Kehidupan Pemerintahan dan Sosial Yang Islami di Desa Tonrong Rijang Kabupaten Sidenreng Rappang. Prosiding Seminar Nasional, Reformasi Dan Inovasi Tata Kelola Pemerintahan, 289 - 307. Retrieved from https://www.researchgate.net/publication/330101808_Perencanaan_M ewujudkan_Kehidupan_Pemerintahan_dan_Sosial_Yang_Islami_di_Desa _Tonrong_Rijang_Kabupaten_Sidenreng_Rappang

Mustanir, A. (2017). Deskripsi Tentang Keamanan Di Gedung dan Jalanan Kota Kuala Lumpur. Kuala Lumpur. Retrieved from https://www.researchgate.net/publication/331064740_Deskripsi_Tenta ng_Keamanan_Di_Gedung_dan_Jalanan_Kota_Kuala_Lumpur

Mustanir, A. (2018). Pemanfaatan Teknologi Informasi Dalam Optimalisasi Pelayanan Publik dan Potensi Desa Sereang. Rappang. Retrieved from https://www.researchgate.net/publication/331064206_Pemanfaatan_T eknologi_Informasi_Dalam_Optimalisasi_Pelayanan_Publik_dan_Potensi _Desa_Sereang

Mustanir, A., \& Abadi, P. (2017). PARTISIPASI MASYARAKAT DALAM MUSYAWARAH RENCANA PEMBANGUNAN DI KELURAHAN 
KANYUARA KECAMATAN WATANG SIDENRENG KABUPATEN SIDENRENG RAPPANG. Jurnal Politik Profetik, 5(2), 247-261. Retrieved from http://journal.uinalauddin.ac.id/index.php/jpp/article/viewFile/4347/3986

Mustanir, A. D. (2016). IMPLEMENTASI KEBIJAKAN DANA DESA DAN PARTISIPASI MASYARAKAT DALAM PEMBANGUNAN DI DESA TETEAJI KECAMATAN TELLU LIMPOE KABUPATEN SIDENRENG RAPPANG. Jurnal Politik Profetik, 04(2), 225-238. Retrieved from http://journal.uin-alauddin.ac.id/index.php/jpp/article/view/2749

Mustanir, A., \& Jaya, I. (2016). PENGARUH KEPEMIMPINAN DAN BUDAYA POLITIK TERHADAP PERILAKU PEMILIH TOWANI TOLOTANG DI KECAMATAN MARITENGNGAE KABUPATEN SIDENRENG RAPPANG. Jurnal Politik Profetik, 04(1), 84-97. Retrieved from http://journal.uinalauddin.ac.id/index.php/jpp/article/view/2741\#

Mustanir, A., \& Jusman. (2016). IMPLEMENTASI KEBIJAKAN DAN EFEKTIVITAS PENGELOLAAN TERHADAP PENERIMAAN RETRIBUSI DI PASAR LANCIRANG KECAMATAN PITU RIAWA KABUPATEN SIDENRENG RAPPANG. Jurnal Ilmiah Akmen.

Mustanir, A., Justira, N., Sellang, K., \& Muchtar, A. I. (2018). Democratic Model On Decision-Making At Deliberations Of Development Planning. International Conference on Government Leadership and Social Science (ICOGLASS). Demanding Governance Accountability and Promoting Democratic Leadership for Public Welfare Achievement, 110 - $115 . \quad$ Retrieved from https://www.researchgate.net/publication/330090538_Democratic_Mo del_On_Decision-Making_At_Deliberations_Of_Development_Planning

Mustanir, A., \& Lubis, S. (2017). Participatory Rural Appraisal in Deliberations of Development Planning. In International Conference On Democracy, Accountability, and Governance (ICODAG 2017) (Vol. 163, pp. 316-319). Pekanbaru: Atlantis Press. https://doi.org/10.2991/icodag-17.2017.60.

Mustanir, A., \& Razak, M. R. R. (2017). Nilai Sosial Budaya Pada Partisipasi Masyarakat Etnik Towani Tolotang Dalam Musyawarah Rencana Pembangunan (pp. 8-9). Pare Pare: Penerbit Program Pascasarjana Universitas Muhammadiyah Yogyakarta. Retrieved from http://asosiasipascaptm.or.id/index.php/publikasi/prosidingkonferensi-nasional-appptma-ke-6 
Mustanir, A., \& Rusdi. Muhammad. (2019). Participatory Rural Appraisal (PRA) Sebagai Sarana Dakwah Muhammadiyah Pada Perencanaan Pembangunan Di Kabupaten Sidenreng Rappang. In Konferensi Nasional Ke-8 Asosiasi Program Pascasarjana Perguruan Tinggi Muhammadiyah Aisyiyah (APPPTMA) (pp. 378-383). Medan: Penerbit Program Pascasarjana Universitas Muhammadiyah Yogyakarta. Retrieved from http://asosiasipascaptm.or.id/index.php/publikasi/prosidingkonferensi-nasional-appptma-ke-8

Mustanir, A., \& Rusdi, M. (2019). Participatory Rural Appraisal (PRA) Sebagai Sarana Dakwah Muhammadiyah Pada Perencanaan Pembangunan di Kabupaten Sidenreng Rappang. Prosiding Konferensi Nasional Ke-8 Asosiasi Program Pascasarjana Perguruan Tinggi Muhammadiyah Aisyiyah (APPPTMA). Medan. Retrieved from http://asosiasipascaptm.or.id/index.php/publikasi/prosidingkonferensi-nasional-appptma-ke-8

Mustanir, A., \& Yasin, A. (2018). Community Participation in Transect on Development Planning. Jurnal Ilmiah Ilmu Administrasi Publik: Jurnal Pemikiran Dan Penelitian Administrasi Publik (JIAP), 8(2), 137-146. https://doi.org/https://doi.org/10.26858/jiap.v8i2.7994

Razak, M. R. R., Dahong, M., Ahmad, J., Dema, H., \& Mustanir, A. (2018). The Effect of Siri's Marriage on Government Administration. International Journal of Sciences: Basic and Applied Research (IJSBAR), 42(3), 171-184. Retrieved from http://gssrr.org/index.php?journal= JournalOfBasicAndApplied\&page= article\&op=view\&path\%5B\%5D=9484

Pranarka; Moeldjarto, 1996. Pemberdayaan (Empowerment), Dalam Pemberdayaan, Konsep Kebijakan dan Implementasi. CSIS. Jakarta.

Purnomo, S 2013. Panduan pelaksanaan Kelembagaan Manajemen Kebut Bibit Desa (KBD) pada Model Kawasan Rumah Pangan Lestari (MKRPL). Badan Penelitian dan Pengembangan Pertanian. Kementerian Pertanian.

Ridwan, Zulkarnain. Urgensi Badan Usaha Milik Desa (Bumdes) Dalam Pembangunan Perekonomian. Fiat Justicia Jurnal Ilmu Hukum Volume 8 no 3 Juli-September 2014. ISSN 1978-5186 
Saptari, R., \& Holzner, B. 1997. Perempuan Kerja dan Perubahan Sosial: Sebuah Pengantar Studi Perempuan. Jakarta: Pustaka Utama Grafiti

Subekti, Tia. Arinda, Agies. Pengelolaan BUMDes melalui Good Governance Studi Kasus: BUMDes Tirta Mandiri Desa Ponggok Klaten Jawa Tengah. Program Studi IImu Pemerintahan FISIP Universitas Brawijaya Malang

Suharto, Edi. 2006. Membangun Masyarakat Memberdayakan Rakyat. Bandung : Refika Aditama.

Sumpeno, Wahyudin. Perencanaan Desa Terpadu (Panduan Perencanaan Pembangunan Berbasis Masyarakat). Jakarta : CRS Indonesia.

Supriatna, Tjahya. 2000. Strategi Pembangunan dan Kemiskinan. Jakarta : Rineka Cipta.

Sutoro, Eko dkk. Cetakan Pertama April 2016. Dana Desa Untuk Desa Membangun Indonesia (Tanya Jawab Seputar Dana Desa). Kementerian Desa, Pembangunan Daerah Tertinggal, dan Transmigrasi Republik Indonesia.

Tim Penyusun Kementrian Desa, PDT dan Transmigrasi. Cet 1 Juni 2015. Tanya Jawab Seputar Undang-Undang Desa. Jakarta : Kementrian Desa, PDT dan Transmigrasi.

Wahyuni, 1990. Mobilitas Wanita di Daerah Pedesaan Suatu Studi Kasus di Kabupaten Sleman, DI. Yogya- karta, Tesis, UGM, Yogyakarta.

Wolfman, BR, 1989. Peran Kaum Perempuan: "Bagaimana Menjadi Cakap dan Seimbang dalam Aneka Peran", Cetakan Ketiga, Kanisius, Yogyakarta

\section{Undang-Undang dan Peraturan Lainnya}

PP Nomor 72 Tahun 2005 tentang Desa

PP 22 Tahun 2015 Perubahan PP 60 Dana Desa

PP 43 Tahun 2014 Peraturan Pelaksanaan UU Desa

PP 47 Tahun 2015 - Perubahan PP No 43 Tahun 2014 Tentang Peraturan Pelaksanaan UU No 06 Tahun 2014

PP 60 Tahun 2014 tentang Dana Desa dari APBN 
Peraturan Menteri dalam Negeri Nomor 66 Tahun 2007 tentang Perencanaan Pembangunan Desa

Peraturan Menteri Dalam Negeri nomor 39 tahun 2010 tentang Badan Usaha Milik Desa

Permendagri No. 113-2014 Pedoman Pengelolaan Keuangan Desa

Permendagri No. 114-2014 Pembangunan Desa

Permendesa Nomor 4 tahun 2015 tentang 2015 tentang Pendirian Pengurusan Dan Pengeloelaan Dan Pembubaran Badan Usaha Milik Desa

Permendesa No 3-2015 Pendampingan Desa

Undang-Undang Nomor 6 Tahun 2014 tentang Desa

Undang-Undang Nomor 23 tahun 2014 tentang Pemerintahan Daerah 


\section{LAMPIRAN-LAMPIRAN}

\section{Foto Lokasi Pengabdian Masyarakat via google map}

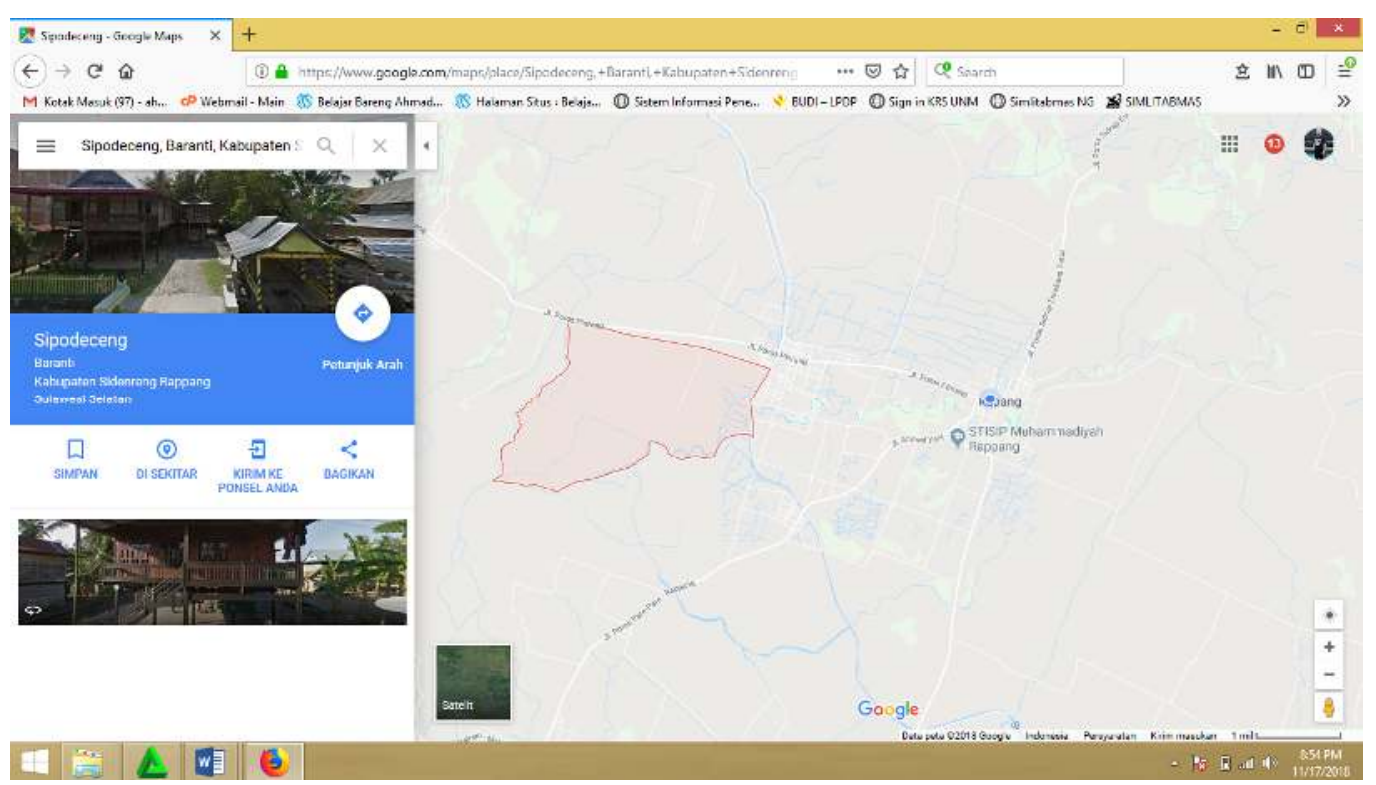

